\title{
Description of Immature Stages of Culex ocossa Dyar \& Knab, Culex delpontei Duret and Culex pereyrai Duret of the Melanoconion Subgenus (Diptera: Culicidae)
}

\author{
Maria Anice Mureb Sallum ${ }^{+}$, Keilla Miki Kobayashi, Oswaldo Paulo Forattini
}

\begin{abstract}
Departamento de Epidemiologia, Núcleo de Pesquisa Taxonômica e Sistemática em Entomologia Médica, Faculdade de Saúde Pública, Universidade de São Paulo, Av. Dr. Arnaldo 715, 01246-904 São Paulo, SP, Brasil

The larva and pupa of Culex (Melanoconion) ocossa Dyar \& Knab are redescribed and those of Culex (Melanoconion) delpontei Duret and Culex (Melanoconion) pereyrai Duret are described from specimens collected in the states of São Paulo and Paraná, Brazil. The pupa of Cx. ocossa differs from those of the other two species in having seta 5-IV-VI dark with strongly aciculated branches, and caudolateral angle of segment VIII produced into sharp point, and seta 1-P present; Cx. delpontei can be distinguished from $\mathrm{Cx}$. pereyrai in possessing paddle lightly tanned, trumpet flared, and wing and leg cases lightly tanned, without pattern of dark spots; Cx. pereyrai can be recognized by having wing case with pattern of dark, discontinuously pigmented, longitudinal lines, and trumpet cylindrical, not flared. The larvae of the three species share the presence of seta 2-C placed medially to seta 1-C.
\end{abstract}

Key words: systematics - Culicidae - Culex - Melanoconion - immatures

The Crybda Group of the Spissipes Section of Culex (Melanoconion), proposed by Sallum and Forattini (1996), includes three subgroups, Pedroi (Cx. pedroi Sirivanakarn \& Belkin, Cx. adamesi Sirivanakarn \& Galindo, $C x$. crybda Dyar, $C x$. epanastasis Dyar, and $C x$. ribeirensis Forattini \& Sallum), Paracrybda (Cx. paracrybda Komp, and $C x$. delpontei Duret), and Pereyrai (Cx. pereyrai Duret). The Crybda Group can be easily recongnized by male genitalic features. The division in subgroups was mainly based on morphological features of adult, cibarial armature and male genitalia. The Ocossa Group which includes $C x$. ocossa Dyar \& Knab and $C x$. panocossa Dyar can be distinguished from the Crybda Group by features of male genitalia, adult, and particularly from the Pedroi Subgroup, by female cibarial armature.

$C x$. delpontei was demonstrated to be a potential vector in enzootic patterns of transmission of VEE virus subtype VI and several other Bunyaviridae in Chaco and Santa Fe Provinces in Argentina (Mitchell et al. 1985, 1987). Cx. ocossa was supposed to be involved in the transmission

Supported by grant no. 99/10517-1, Fundação de Amparo à Pesquisa do Estado de São Paulo, Brasil. ${ }^{+}$Corresponding author. Fax: +55-11-3081.2108. E-mail: masallum@usp.br

Received 17 January 2001

Accepted 25 April 2001 of WEE virus in Chaco and Corrientes, Argentina (Sirivanakarn \& Jakob 1981) and showed to be a potential vector of wild strain of VEE virus, and strain I-D of VEE virus in laboratory condition (Galindo \& Grayson 1971, Galindo 1972, Galindo \& Adames 1973). No data are available about medical importance of $C x$. pereyrai and little is known about the habitats of the adults and immature stages (Sallum \& Forattini 1996). Immatures of $C x$. ocossa were briefly described and illustrated by Belkin et al. (1970) as basis for the identification of $C x$. panocossa from Jamaica, and those of $C x$. delponte $i$ and $C x$. pereyrai were unknown until now.

During ecological studies carried out in the Ribeira Valley, São Paulo, Brazil, the immatures of Cx. ocossa, Cx. delponte $i$ and $C x$. pereyra $i$ were collected. The study of them has shown that larval and pupal stages of $C x$. delpontei and $C x$. pereyrai are in general similar to those of $C x$. ocossa. For this reason, we report here, for the first time, the descriptions and illustrations of larval and pupal stages of $C x$. delpontei and $C x$. pereyrai, and redescribe those of $C x$. ocossa.

\section{MATERIALS AND METHODS}

All specimens examined during this study came from collections of immature stages made during ecological studies carried out in the states of São Paulo and Paraná, Brazil.

Immatures were identified by means of comparison with specimens associated with adult stages. Collection data are given as follows: 
COUNTRY, State, City, Locality, collection date, collector, number of specimens examined, and life stages. Measurements were taken from ten individuals except when indicated. The specimens studied are deposited in the Entomological Collection of the Faculdade de Saúde Pública, Universidade de São Paulo (FSP-USP), Brazil. Asterisk (*) following an abbreviation for any life stage indicates that at least part of the lineage was illustrated in the publication cited.

\section{RESULTS}

\section{Culex (Melanoconion) ocossa Dyar \& Knab, 1919}

Culex (Melanoconion) ocossa Dyar \& Knab, 1919: $6\left(\sigma^{*}\right)$. Lectotype: British Guyana [Georgetown, Guyana] [NMNH]. Belkin et al. 1970:\#93 ( o* $\left.^{*}, \mathrm{P}^{*}, \mathrm{~L}^{*}\right)$

Pupa (Fig. 1) - Position and development of stage as figured, range and modal number of branches in Table I. Cephalothorax: lightly tanned, leg and wing cases usually speckled, sometimes without pattern of dark spots. Trumpet: moderately tanned, flared, index 6.0-9.0 (mean = 7.56) $(n=$ $9)$; tracheoid area extending 0.30-0.46 (mean = $0.38)(n=9)$ from base; pinna large, V-shaped, about 0.42 of trumpet length, meatus with short slit. Abdomen: lightly tanned, tergum VIII darker, more evident on central and posterior portions; length 1.91-2.26 mm (mean $=2.12 \mathrm{~mm})(n=6)$. Seta 1-II with 5-10 weak branches; 1-III-V with multiple, simple branches; 5-III weak with simple branches, 5-IV-VI dark with strong, aciculate branches; 9-VIII inserted at caudolateral angle. Caudolateral angle produced into sharp point.
Genital lobe: lightly tanned in female, darker in male; length about $0.19 \mathrm{~mm}(n=1)$, in female; $0.29-0.32 \mathrm{~mm}$ (mean $=0.30 \mathrm{~mm})(n=8)$ in male. Paddle: lightly tanned, darker on apex and nearly all inner side, midrib strong except at apex, more tanned on apical end; buttress developed at base only; margins smooth; length $0.64-0.71 \mathrm{~mm}$ (mean $=0.67 \mathrm{~mm})(n=9)$, width $0.42-0.48 \mathrm{~mm}$ (mean $=$ $0.46 \mathrm{~mm})$, index $1.38-1.52(\mathrm{X}=1.47)$; seta $2-\mathrm{P}$ absent, 1-P weak, always single.

Larva (Fig. 2) - Position and development of setae as figured; range and modal number of branches in Table II. Head: wider than long, length $0.65-0.74 \mathrm{~mm}$ (mean $=0.69 \mathrm{~mm})(n=9)$; width $0.97-1.04 \mathrm{~mm}($ mean $=1.0 \mathrm{~mm})$; moderately tanned, darker on anterior end of dorsal apotome, collar and median labral plate. Median labral plate prominent, anterior margin between seta 1-C concave. Dorsomentum nearly triangular with a large median tooth and 3-6 smaller, unequally developed teeth on either side of median tooth. Antenal length $0.50-0.64 \mathrm{~mm}($ mean $=0.57 \mathrm{~mm})(n=10)$; antenna lightly pigmented, darker on base and distally to seta $1-\mathrm{A}$; seta 1 -A inserted $0.57-0.63$ (mean $=0.61$ ) from base with 26-36 strongly aciculate branches; 2,3-A apical in position. Antenal puncture distinct. Seta 2-C present, well developed, inserted medially to seta $1-\mathrm{C}$; $3-\mathrm{C}$ present, minute; 4-C moderately long, almost reaching the level of insertion of seta 7-C; 5-C well developed with strong, densely aciculate branches; 6-C long with tiny spicules. Thorax: integument hyaline with tiny spicules, these more evident laterally and on ventral surface; thoracic segments without patches of

TABLE I

Pupal setal branching for Culex ocossa: range, mode ( $)^{a}$

\begin{tabular}{|c|c|c|c|c|c|c|c|c|c|c|c|}
\hline \multirow{2}{*}{$\begin{array}{l}\text { Seta } \\
\text { no. }\end{array}$} & \multirow[t]{2}{*}{ Cephalothorax } & \multicolumn{9}{|c|}{ Abdominal segments } & \multirow[t]{2}{*}{ Paddle } \\
\hline & & I & II & III & IV & $\mathrm{V}$ & VI & VII & VIII & IX & \\
\hline 0 & - & - & 1 & 1 & 1 & 1 & 1 & 1 & 1 & - & - \\
\hline 1 & $2-4(3)$ & 7-11(9) & $5-10(6)$ & $5-10(6)$ & $4-7(5)$ & $2-5(4)$ & $2-5(3)$ & $2-4(3)$ & - & $1,2(1)$ & $1,2(1)$ \\
\hline 2 & $2-5(3)$ & $1,2(1)$ & 1 & 1 & 1 & 1 & 1 & 1 & - & - & - \\
\hline 3 & $2-3(2)$ & $1,2(1)$ & $1,2(2)$ & $1,2(1)$ & $3-6(4)$ & $1,2(2)$ & $1-3(2)$ & $2-4(3)$ & - & - & - \\
\hline 4 & $1-3(2)$ & $4-7(5)$ & $2-5(3)$ & $3-5(4)$ & $2-4(3)$ & $3-6(5)$ & $1-4(2)$ & $1,2(2)$ & $1-3(2)$ & - & - \\
\hline 5 & $3-6(4)$ & $2,3(2)$ & $2-4(4)$ & $3-6(5)$ & $6-9(6)$ & $4-7(6)$ & $4-6(5)$ & $1-3(2)$ & - & - & - \\
\hline 6 & $1,2(2)$ & 1 & $1,2(1)$ & $1,2(2)$ & 2 & 2 & $1,2(2)$ & $2-4(3)$ & - & - & - \\
\hline 7 & $2,3(2)$ & $1-3(2)$ & $1,2(2)$ & 4 & $2-4(3)$ & $3-5(4)$ & 1 & 1 & - & - & - \\
\hline 8 & $3-5(3)$ & - & - & $2-4(3)$ & $2,3(3)$ & $2-4(3)$ & $2-5(3)$ & $2-4(3)$ & - & - & - \\
\hline 9 & $1,2(2)$ & 1 & 1 & 1 & 1 & 1 & 1 & $1,2(1)$ & $1,2(1)$ & - & - \\
\hline 10 & $6-9(6)$ & alveolus & - & $1,2(1)$ & 1 & 1 & 1 & $1,2(1)$ & - & - & - \\
\hline 11 & 2 & 1 & - & 1 & 1 & 1 & $1,2(1)$ & $1,2(2)$ & - & - & - \\
\hline 12 & $1-3(2)$ & - & - & - & - & - & - & - & - & - & - \\
\hline 13 & - & - & - & - & - & - & - & - & - & - & - \\
\hline 14 & - & - & - & 1 & 1 & 1 & 1 & 1 & 1 & - & - \\
\hline
\end{tabular}

$a$ : based on counts made on 15 to 20 setae. 


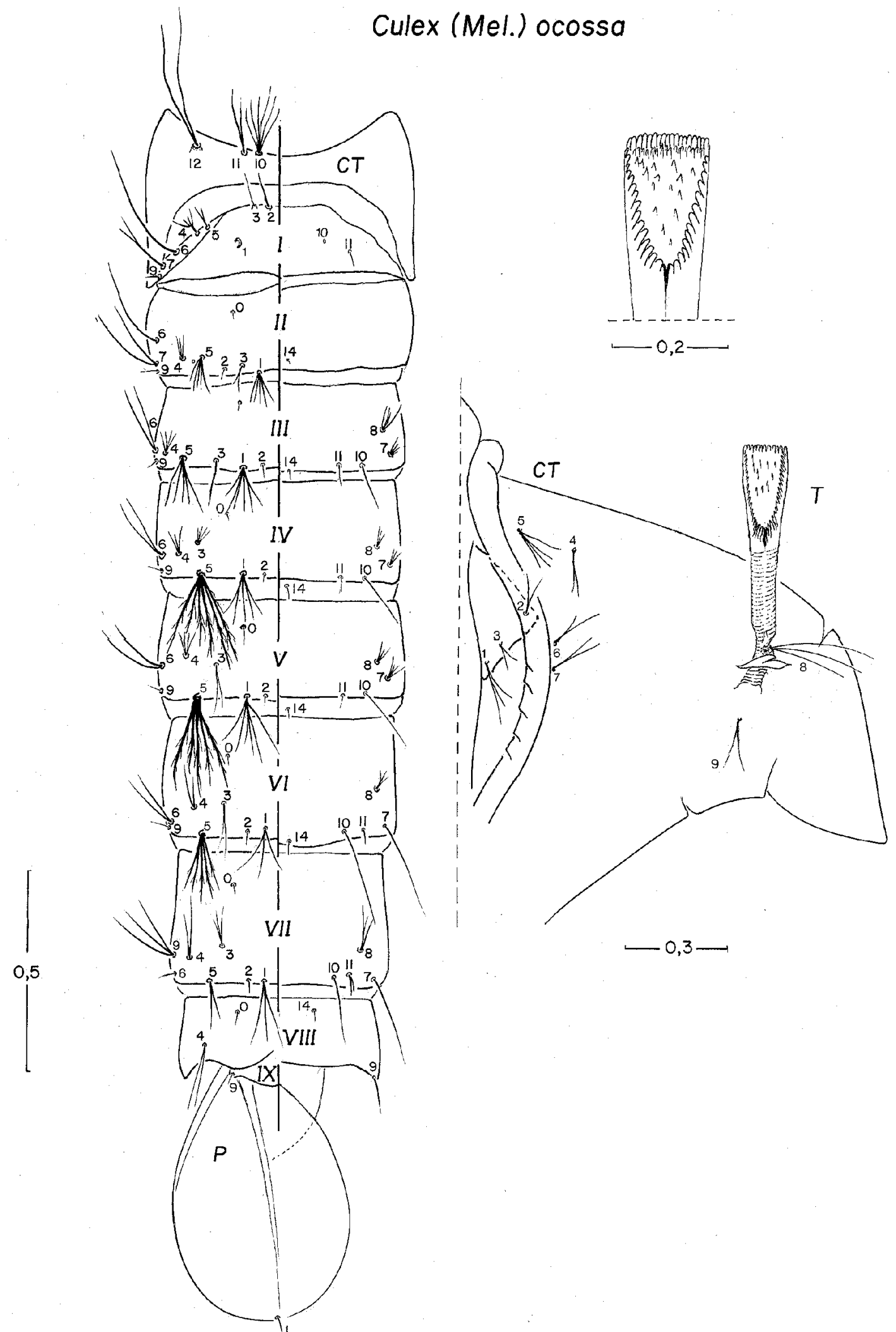

Fig. 1: Culex ocossa. Pupa. CT: cephalothorax; P: paddle; T: trumpet; I-IX: abdominal segments, left side dorsal, right side ventral; scale in $\mathrm{mm}$ 


\section{Culex (Mel.) ocossa}
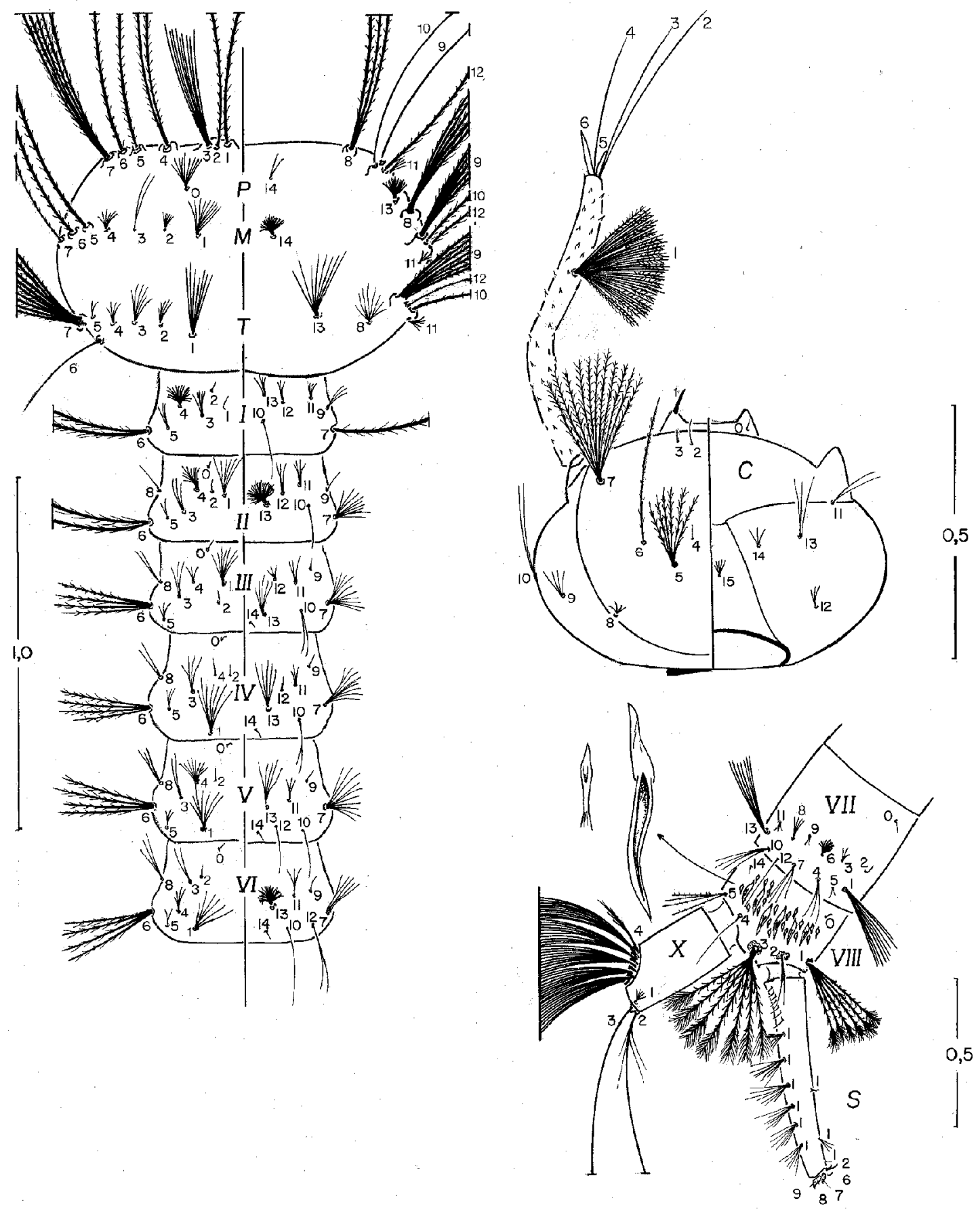

Fig. 2: Culex ocossa. Larva. C: head; P: prothorax; M: mesothorax; S: siphon; T: metathorax; I-VIII: abdominal segments; X: anal lobe; scale in $\mathrm{mm}$ 
TABLE II

Larval setal branching for Culex ocossa: range, mode ()$^{a}$. A range shown without a mode indicates that the mode was indefinite

\begin{tabular}{|c|c|c|c|c|c|c|c|c|c|c|c|c|c|}
\hline \multirow{2}{*}{$\begin{array}{l}\text { Seta } \\
\text { no. }\end{array}$} & \multirow[t]{2}{*}{ Head } & \multicolumn{3}{|c|}{ Thorax } & \multicolumn{9}{|c|}{ Abdominal segments } \\
\hline & & $\mathrm{P}$ & M & $\mathrm{T}$ & I & II & III & IV & $\mathrm{V}$ & VI & VII & VIII & $\mathrm{X}$ \\
\hline 0 & alveolus & $9-15(9)$ & - & - & - & 1 & 1 & 1 & $1,2(1)$ & 1 & 1 & 1 & - \\
\hline 1 & 1 & 1 & $7-11(9)$ & $4-8(7)$ & $1-3(1)$ & $5-8(6)$ & $6-11(7)$ & $3-10(7)$ & $5-9(7)$ & $3-7(6)$ & $7-12(9)$ & $5-7(6)$ & $4-7(5)$ \\
\hline 2 & 1 & 1 & $4-8(6)$ & $3-6(5)$ & $1,2(1)$ & 1 & $1,2(1)$ & 1 & 1 & 1 & 1 & $1-3(2)$ & $5,6(5)$ \\
\hline 3 & 1 & $5-10(9)$ & $1,2(2)$ & $4-8(6)$ & $3-5(5)$ & $1-4(3)$ & $3,4(3)$ & $2-6(4)$ & $2-4(2)$ & $2,3(2)$ & $3-6(3)$ & $7-9(8)$ & 1 \\
\hline 4 & 1 & $2,3(2)$ & $4-7(6)$ & $3-5(4)$ & $12-17(15)$ & $5-11(9)$ & $2-4(3)$ & $1-3(1)$ & $7-10(9)$ & $3-5(4)$ & $2-4(3)$ & 1 & $5-12(8)$ \\
\hline 5 & $5-7(6)$ & 1 & 1 & $1-3(2)$ & $2-4(4)$ & $1-3(2)$ & $2,3(3)$ & $2-5(3)$ & $2-4(3)$ & $2-5(2)$ & $2-4(2)$ & $4-6(4)$ & - \\
\hline 6 & $1,2(1)$ & 1 & 1 & 1 & 2 & 2 & $3-5(4)$ & $2-4(4)$ & $3-5(4)$ & $3-6(4)$ & $10-18(16)$ & $1 \mathrm{a}-\mathrm{S}$ & $3-10(6)$ \\
\hline 7 & 8-13(11) & $3-5(5)$ & 1 & $6-10(9)$ & 1 & $8-12(9)$ & 8-11(10) & $7-10(9)$ & $9-12(10)$ & $3-6(5)$ & $3-6(4)$ & $1 b-S$, & $5-8(7)$ \\
\hline 8 & $3-6(4)$ & $2-5(3)$ & $5-7(5)$ & $6-10(8)$ & - & $1,2(1)$ & $2,3(2)$ & $2,3(2)$ & $2,3(3)$ & $2-3(3)$ & 4-7(4) & $1 \mathrm{c}-\mathrm{S}$ & $5-8(7)$ \\
\hline 9 & $5-9(6)$ & $1,2(1)$ & $5,6(5)$ & $6-9(7)$ & $2-5(3)$ & 1 & 1 & 1 & 1 & 1) & $1-3(2)$ & $1 \mathrm{~d}-\mathrm{S}$ & $1-5(3)$ \\
\hline 10 & $3,4(3)$ & 1 & 1 & 1 & 1 & 1 & $1-3(2)$ & $1,2(2)$ & 1 & $1,2(2)$ & $3-5(4)$ & $1 \mathrm{e}-\mathrm{S}$ & $6-8(7)$ \\
\hline 11 & $1,3(2)$ & $3-6(4)$ & $2-4(4)$ & $3-5(5)$ & $3-6(4)$ & $2-4(4)$ & $3,4(3)$ & $2-5(3)$ & $2-4(3)$ & $2-5(3)$ & $2-4(3)$ & $1 \mathrm{f}-\mathrm{S}$ & $5-8(7)$ \\
\hline 12 & $3-5(3)$ & 1 & 1 & 1 & $3,4(3)$ & $3,4(3)$ & $3,4(3)$ & 1 & 1 & 1 & $1,2(1)$ & $\begin{array}{c}1 \mathrm{~g}-\mathrm{S}, \\
1 \mathrm{~h}-\mathrm{S}, \\
2 \mathrm{~S}\end{array}$ & $\begin{array}{c}5-8 \\
1 \\
2 \\
\end{array}$ \\
\hline 13 & $2-5(3)$ & - & n.c. & $6-11(8)$ & $3-6(4)$ & $23-33(29)$ & $4-6(5)$ & $3-6(5)$ & $4-7(6)$ & n.c. & $4-8(7)$ & - & - \\
\hline 14 & $2-4(3)$ & $2-3(2)$ & n.c. & - & - & - & 1 & 1 & $1,2(1)$ & 1 & 1 & $1,2(1)$ & - \\
\hline 15 & $4-6(5)$ & - & - & - & - & - & - & - & - & - & - & - & - \\
\hline
\end{tabular}

$a$ : based on counts made on 11 to 28 setae; n.c.: not counted; P: prothorax; M: mesothorax; T: metathorax 
black pigment granules under integument. Seta 1,2$\mathrm{P}$ with long aciculae; 3-P with 5-10 aciculate branches; 4-P triple, branches with long aciculae; 1-M well developed, with finely, aciculate branches; 1-T smaller than 1-M; 13-T well developed with sparsely aciculate branches. Abdomen: integument hyaline with tiny spicules on central areas of segments, smooth laterally, spicules more evident on segment VIII, without band of black pigment under integument. Seta 1-I weakly developed, 1-II-V well developed; 6-I, II long with 2 strong, aciculate, unequal branches, 6-III-VI nearly similar in development with finely aciculate branches. Comb with 13-25 short scales interspersed with 4-6 long scales, short scales with distinct apical fringe, lateral fringe less developed, long scales spinelike, sharply pointed, with minute fringe on sides. Siphon: index 4.47-5.31 (mean = 5.11 ), lightly tanned, slightly darker on apex, acus attached, long and slender on anterior side of attachment. Pecten of 5-10 spines on basal 0.30 of siphon; ventral edges of spines fringed with minute, closely set denticles. Seta 1-S usually in 8 pairs, 6 posterior pairs and 2 anterior pairs; posterior pairs with length 1.50 as long as width of siphon at point of insertion, the most anterior pair nearly as long as width of siphon at point of insertion, the most posterior pair minute, inserted dorsally on posterior end of siphon. Seta 2-S inserted in a membrane near base of anterolateral spiracular lobe, curved anteriorly with a small, curved secondary branch near middle of anterior side. Segment X: saddle complete without acus, finely spiculated; anal lobe finely spiculated; length $0.35-0.41 \mathrm{~mm}$ ( mean $=0.38 \mathrm{~mm}$ ); siphon/saddle index 2.02-2.33 $($ mean $=2.15)$. Seta $2-X$ with 1 long and 4,5 short branches; $4-X$ with 6 pairs of setae, 3 anterior pairs with 5-12 branches, 3 posterior pairs with 5-10 branches. Anal papillae long and slender, gradually tapering to blunt tip, dorsal pair about 0.53 length of saddle, ventral pair about 0.84 length of saddle.

Diagnosis - Cx. ocossa can be easily identified by the following characters. Pupa: trumpet moderately tanned, flared, index 6.0-9.0, pinna large, about 0.42 of trumpet length, $\mathrm{V}$-shaped; cephalothoracic integument lightly tanned, wing and leg cases speckled; seta 1-II weakly developed with 5-10 branches; 5-IV-VI strong with densely aciculated, dark branches; abdominal segment VIII moderately tanned, darker than anterior segments, caudolateral angle produced into sharp point; paddle lightly tanned, darker on apex and nearly all inner side; seta 2-P absent, 1-P present. Larva: seta 2-C present, well developed, inserted medially to $1-\mathrm{C} ; 3-\mathrm{C}$ present, minute; $5-\mathrm{C}$ moderately long, not reaching anterior margin of head, with 5-
7 strong, aciculate branches; median labral plate prominent, anterior margin between seta $1-\mathrm{C}$, concave; 7-I single; 1-II well developed, multibranched; comb with 13-25 short scales interspersed with 4-6 long, strong, spinelike scales, short scales disposed in an irregular row; siphonal index 4.47-5.31, siphon lightly tanned, slightly darker on apex; seta 1-S in 6 posterior pairs and 2 anterior pairs; saddle and anal lobe finely spiculated and anal papillae shorter than length of saddle.

Bionomics - Immature stages of $C x$. ocossa were collected in artificial lakes in peridomiciliary environment and grazing areas, river, river edges and lake margins in forest, drainage ditches in cultivated areas, gardens and by the side of roads in cacao plantations. The breeding sites were always permanent, in full sun or partial shade. The water was fresh, clear, light amber or brown in color with slow current and abundant floating vegetation (Pistia, Eichhornia, Salvinia, Azolla), submerged (Elodea) and herbaceous vegetation, and algae. Some sites had the bottom covered with mud or plant debris and others with cement (Heinemann \& Belkin 1978a,b, 1979). In the Ribeira Valley, southern State of São Paulo, Brazil, immature stages were collected in river edges associated with $C x$. delpontei and $C x$. pereyrai.

Material examined - Nine larval exuviae, 10 pupal exuviae, with associated adults male and female, 10 fourth-instar larvae, bearing the following collection data: BRAZIL, State of São Paulo, Iguape County, Ribeira do Iguape River, Valo Grande Dam, 24-X-1989, coll. Gomes, 2Le, 3 Pe, 3 4th-instar larvae; 4-XII-1989, 6 Le, 6 Pe; Palmeiras Farm, 7-XI-1989, 1 Le, IPe; 20-II-1990, 7 4th-instar larvae.

\section{Culex (Melanoconion) delpontei Duret, 1969}

Culex (Melanoconion) delpontei Duret, 1969:8 ( $\left.{ }^{*} *\right)$. Holotype ơ $^{*}$ Las Palmas, Chaco, Argentina (NMNH)

Pupa (Fig. 3) - Position and development of setae as figured; range and modal numbers of branches in Table III. Cephalothorax: lightly tanned. Trumpet: moderately tanned, flared, index 5.80-8.0 (mean $=7.11)$; tracheoid area extending almost 0.50 from base, pinna large, $\mathrm{V}$-shaped, about 0.45 of trumpet length; meatus with short slit. Abdomen: lightly and evenly tanned; length 2.06-2.64 mm (mean $=2.42 \mathrm{~mm})(n=7)$. Seta 1-II usually with 11 weakly developed branches, 1-III$\mathrm{V}$ with simple branches; 5-III with weak, simple branches, 5-IV-VI with finely aciculated branches, branches stronger than those of 5-III; 9-VIII inserted at caudolateral angle, single; caudolateral angle blunt. Genital lobe: lightly tanned in female, slightly darker in male; length $0.14-0.17 \mathrm{~mm}$ (mean 


\section{Culex (Mel.) delpontei}

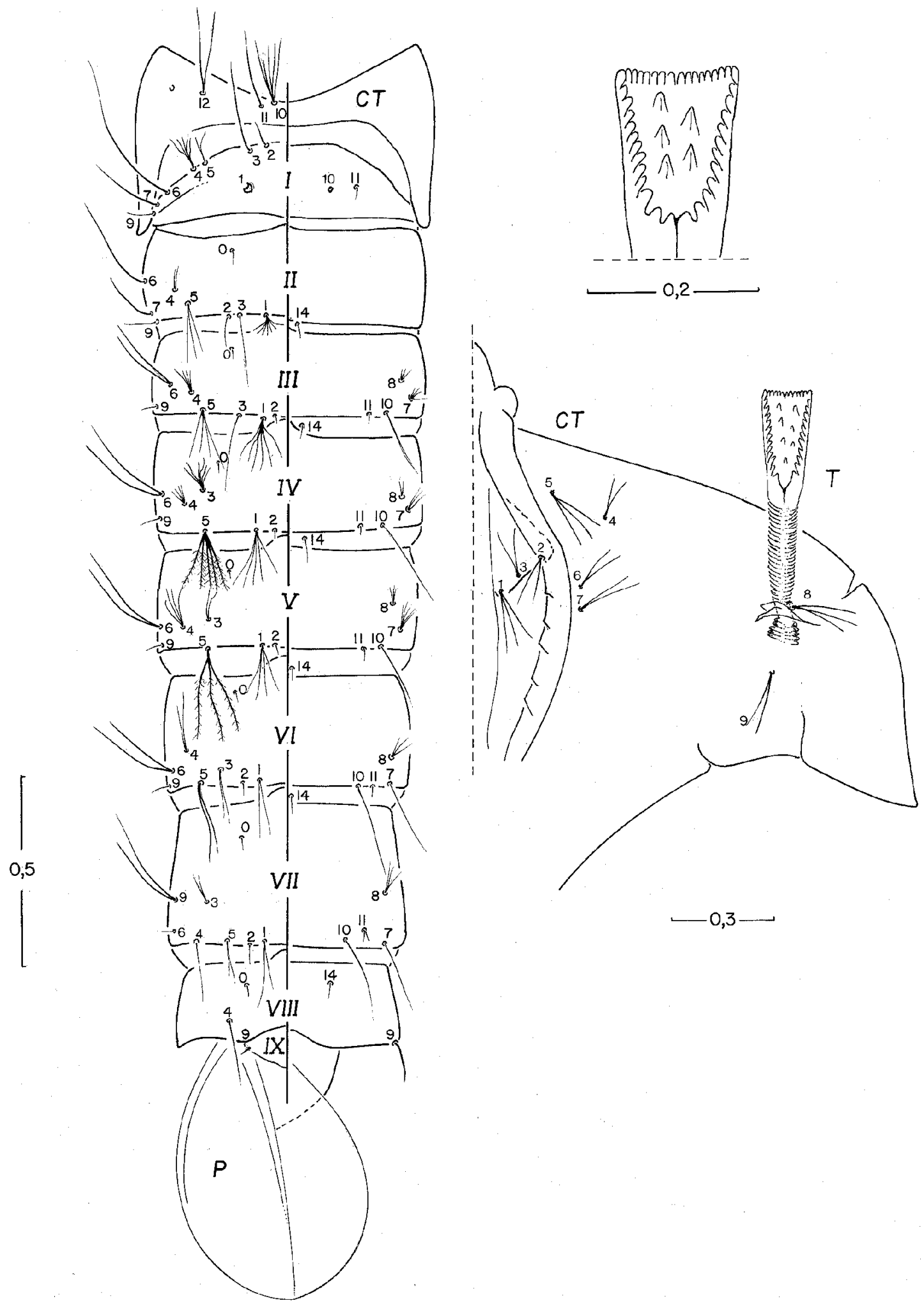

Fig. 3: Culex delpontei. Pupa. CT: cephalothorax; P: paddle; T: trumpet; I-IX: abdominal segments, left side dorsal, right side ventral; scale in mm 
TABLE III

Pupal setal branching for Culex delpontei: range, mode ( $)^{a}$

\begin{tabular}{|c|c|c|c|c|c|c|c|c|c|c|c|}
\hline \multirow{2}{*}{$\begin{array}{l}\text { Seta } \\
\text { no. }\end{array}$} & \multirow[t]{2}{*}{ Cephalothorax } & \multicolumn{9}{|c|}{ Abdominal segments } & \multirow[t]{2}{*}{ Paddle } \\
\hline & & I & II & III & IV & V & VI & VII & VIII & IX & \\
\hline 0 & - & - & 1 & 1 & 1 & 1 & 1 & 1 & 1 & 1 & - \\
\hline 1 & $2-5(3)$ & $4-8(6)$ & $5-20(11)$ & $3-10(6)$ & $4-7(5)$ & $2-5(4)$ & $2-5(2)$ & $1-3(2)$ & - & - & - \\
\hline 2 & $2-4(3)$ & $1,2(1)$ & 1 & 1 & 1 & 1 & 1 & 1 & - & - & - \\
\hline 3 & $2,3(2)$ & 1 & 1 & $1,2(1)$ & $3-7(6)$ & $2,3(2)$ & $1,2(2)$ & $1-3(2)$ & - & - & - \\
\hline 4 & $1-4(2)$ & $3-6(5)$ & $1-4(2)$ & $4-6(4)$ & $2-5(4)$ & $3-7(4)$ & $1-3(2)$ & 2 & $1,2(2)$ & - & - \\
\hline 5 & $2-4(3)$ & $2,3(2)$ & $1-4(3)$ & $3-5(4)$ & $3-7(5)$ & $2-4(3)$ & $2-4(2)$ & $1-3(1)$ & - & - & - \\
\hline 6 & $1-3(2)$ & 1 & 1 & $1,2(2)$ & $1,2(2)$ & 2 & 2 & $2-5(5)$ & - & - & - \\
\hline 7 & $1-3(2)$ & $1,2(1)$ & $1,2(1)$ & $3-5(4)$ & $2-4(3)$ & $3-7(5)$ & 1 & $1,2(1)$ & - & - & - \\
\hline 8 & $2-4(3)$ & - & - & $2-4(3)$ & $1-3(2)$ & $1-3(3)$ & $1-3(3)$ & $1-4(3)$ & - & - & - \\
\hline 9 & $1,2(2)$ & 1 & 1 & $1-4(1)$ & 1 & 1 & 1 & $1-3(1)$ & 1 & - & - \\
\hline 10 & $4-10(5)$ & alveolus & - & $1,2(1)$ & 1 & 1 & 1 & $1,2(1)$ & - & - & - \\
\hline 11 & $1-3(1)$ & $1,2(1)$ & - & 1 & $1,2(1)$ & 1 & 1 & $1,2(2)$ & - & - & - \\
\hline 12 & $1,2(2)$ & - & - & - & - & - & - & - & - & - & - \\
\hline 13 & - & - & - & - & - & - & - & - & - & - & - \\
\hline 14 & - & - & - & 1 & 1 & $1,2(1)$ & 1 & 1 & 1 & - & - \\
\hline
\end{tabular}

$a$ : based on counts made on 11 to 20 setae.

$=0.15 \mathrm{~mm})$, in female; $0.32-0.34 \mathrm{~mm}$ (mean $=0.33$ $\mathrm{mm})(n=5)$, in male. Paddle: lightly tanned; midrib strong except at apex; buttress developed at base only, margins smooth, length $0.65-0.76 \mathrm{~mm}$ (mean $=0.71 \mathrm{~mm}$ ), width $0.46-0.55 \mathrm{~mm}$ (mean $=0.51$ $\mathrm{mm})(n=6)$, index 1.31-1.59 $($ mean $=1.39)(n=$ $6)$; seta 1,2-P absent.

Larva (Fig. 4) - Position and development of setae as figured; range and modal number of branches in Table IV. Head: wider than long; length $0.68-0.80 \mathrm{~mm}$ (mean $=0.75 \mathrm{~mm}$ ); width 1.00-1.16 $\mathrm{mm}($ mean $=1.07 \mathrm{~mm})$; lightly tanned, darker on anterior end of dorsal apotome, collar and median labral plate. Median labral plate prominent, outer margin between seta 1-C straight. Dorsomentum nearly triangular with 1 large median tooth and 4,5 smaller, unequally developed teeth, on either side of median tooth. Antennal length 0.57-0.68 mm ( mean $=0.63 \mathrm{~mm}$ ); antenna lightly tanned, darker on base and distally to seta 1-A; seta 1-A inserted 0.71-0.76 from base with 25-33 strongly aciculated branches; 2,3-A apical in position. Antennal puncture distinct. Seta 2-C present, well developed, inserted medially to seta $1-\mathrm{C}$; $3-\mathrm{C}$ present, minute; 4-C moderately long, extending slightly beyond insertion of seta 7-C; 5-C well developed with 6,7 strong, densely aciculated branches; 6-C single, long, extending nearly 0.5 length of antenna, with long aciculae. Thorax: integument hyaline with tiny spicules, more evident laterally and on ventral surface; thoracic segments without patches of black pigment granules under integument. Seta 1,2-P with long aciculae; 3-P with 6-11 aciculate branches; 4-P with densely aciculated branches; 1-M well developed with sparsely aciculated branches; 1-T smaller than 1-M; 13-T well developed with sparsely aciculated branches. Abdomen: integument hyaline with tiny spicules on central areas of segments, smooth laterally, spicules more evident on segment VIII; segments without bands of black pigments under integument. Seta 1-I weakly developed, 1-II-V well developed with sparsely, aciculated branches; 6-I,II long with 2 strong, aciculate, unequal branches, 6-III-VI similar in development with aciculate branches. Comb with 32-52 short scales interspersed with 4,5 long, strong, sharply pointed, spinelike scales, short scales with distinct apical fringe, lateral fringe less developed, long scales with minute fringe on sides; short scales disposed in 2,3 irregular rows. Siphon: index 5.55-7.23 (mean = 6.29); moderately tanned, acus attached, long and slender on anterior side of attachment. Pecten of 7-10 spines on basal 0.3 of siphon; ventral edges of spines fringed with minute, closely set denticles. Seta 1-S usually in 11 pairs, 6,7 posterior pairs and 4 anterior pairs; posterior pairs with length 1.40 as long as width of siphon at point of insertion, anterior pairs nearly as long as width of siphon at point of insertion, except the most posterior pair which is minute, inserted dorsally on posterior end of siphon. Seta 2-S arising in a membrane near base of anterolateral spiracular lobe, curved anteriorly with a small curved secondary branch near middle of anterior side. Segment X: saddle complete, without acus, finely spiculated; anal lobe finely spiculated; length 0.38 - 


\section{Culex (Mel.) delpontei}
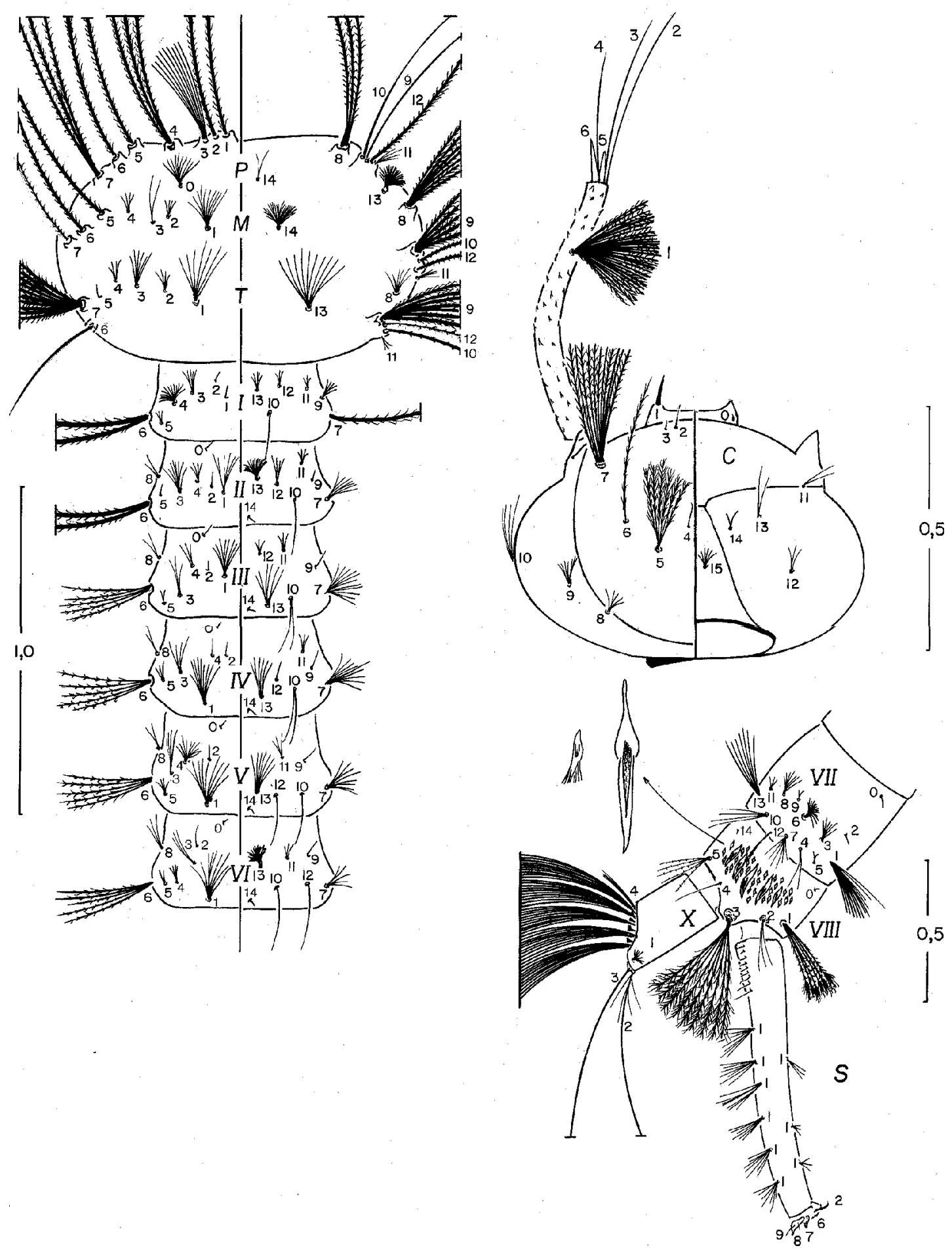

Fig. 4: Culex delpontei. Larva. C: head; P: prothorax; M: mesothorax; S: siphon; T: metathorax; I-VIII: abdominal segments; X: anal lobe; scale in $\mathrm{mm}$ 
TABLE IV

Larval setal branching for Culex delpontei: range, mode ( $)^{a}$. A range shown without a mode indicates that the mode was indefinite

\begin{tabular}{|c|c|c|c|c|c|c|c|c|c|c|c|c|c|}
\hline \multirow{2}{*}{$\begin{array}{l}\text { Seta } \\
\text { no. }\end{array}$} & \multirow[t]{2}{*}{ Head } & \multicolumn{3}{|c|}{ Thorax } & \multicolumn{9}{|c|}{ Abdominal segments } \\
\hline & & $\mathrm{P}$ & M & $\mathrm{T}$ & I & II & III & IV & $\mathrm{V}$ & VI & VII & VIII & $X$ \\
\hline 0 & alveolus & $8-16(15)$ & - & - & - & 1 & 1 & 1 & 1 & 1 & 1 & $1,2(1)$ & - \\
\hline 1 & 1 & 1 & $5-12(10)$ & $5-9(7)$ & $1-4(1)$ & $5-8(6)$ & $7-10(8)$ & $8-10(9)$ & 7-11(9) & $4-10(9)$ & $9-14(12)$ & $5-8(6)$ & $5-8(7)$ \\
\hline 2 & 1 & 1 & $3-6(4)$ & $4-6(4)$ & $1,2(1)$ & 1 & 1 & 1 & 1 & 1 & 1 & $1-4(3)$ & $5-7(5)$ \\
\hline 3 & 1 & $6-11(9)$ & $1,2(2)$ & $6-9(7)$ & $2-8(5)$ & $3-8(4)$ & $2-5(3)$ & $3-5(4)$ & $2-4(3)$ & $1-3(3)$ & $4-7(6)$ & $8-12(9)$ & 1 \\
\hline 4 & 1 & 3 & $4-7(5)$ & $2-5(4)$ & $12-23(13)$ & $5-11(8)$ & $2-4(3)$ & $1,2(1)$ & $9-13(10)$ & $4-7(5)$ & $2-5(4)$ & 1 & $4-10(9)$ \\
\hline 5 & $6,7(7)$ & 1 & 1 & $1,2(1)$ & $2-5(3)$ & $1,2(1)$ & $1,2(2)$ & $2-4(3)$ & $2-4(4)$ & $2-4(2)$ & $2-4(2)$ & $4-6(5)$ & - \\
\hline 6 & 1 & 1 & 1 & 1 & 2 & 2 & $4-6(5)$ & $4,5(5)$ & $3-6(5)$ & $4-7(5)$ & $13-20(14)$ & 1a-S, & $3-10(6)$ \\
\hline 7 & $10-15(11)$ & $3-7(5)$ & 1 & $7-13(10)$ & 1 & $7-11(7)$ & $8-14(11)$ & $8-13(9)$ & $8-15(8)$ & $4-7(6)$ & $3-6(6)$ & $\begin{array}{l}1 \mathrm{~b}-\mathrm{S}, \\
1 \mathrm{c}-\mathrm{S}, \\
1 \mathrm{~d}-\mathrm{S},\end{array}$ & $\begin{array}{c}6-9(7) \\
2-5(2) \\
6-10(8)\end{array}$ \\
\hline 8 & $4-8(6)$ & $2-4(3)$ & $5-8(7)$ & $7-9(8)$ & - & $1-3(2)$ & $2,3(2)$ & $1-3(2)$ & $1,2(2)$ & $2-4(3)$ & $4-8(7)$ & $\begin{array}{l}1 \mathrm{e}-\mathrm{S} \\
1 \mathrm{f}-\mathrm{S}\end{array}$ & $\begin{array}{c}6-10(8) \\
1-3(2)\end{array}$ \\
\hline 9 & $5-9(7)$ & 1 & $5-8(5)$ & $6-9(7)$ & $2-5(5)$ & 1 & 1 & 1 & 1 & 1 & $2-4(2)$ & $\begin{array}{l}1 \mathrm{~g}-\mathrm{S}, \\
1 \mathrm{~h}-\mathrm{S},\end{array}$ & $\begin{array}{c}6-10(8) \\
6-9(8)\end{array}$ \\
\hline 10 & $2-5(4)$ & 1 & 1 & 1 & 1 & 1 & $1-3(2)$ & $1-3(2)$ & 1 & 1 & $2-5(4)$ & $1 \mathrm{i}-\mathrm{S}$ & $3-7$ \\
\hline 11 & $2-4(2)$ & $2-5(5)$ & $3-5(4)$ & $2-4(3)$ & $2-5(4)$ & $3-6(4)$ & $2,3(3)$ & $2-4(3)$ & $1-4(3)$ & $2-4(3)$ & $2-4(3)$ & $\begin{array}{c}1 \mathrm{j}-\mathrm{S}, \\
\mathrm{lk}-\mathrm{S}, \\
2-\mathrm{S},\end{array}$ & $\begin{array}{c}2-6(3) \\
1 \\
2 \\
\end{array}$ \\
\hline 12 & $2,3(3)$ & 1 & 1 & 1 & $3,4(3)$ & $3-5(4)$ & $2-4(3)$ & $1,2(1)$ & $1,2(1)$ & 1 & 1 & & \\
\hline 13 & $1-3(2)$ & - & n.c. & $6-11(10)$ & $3-6(5)$ & $13-34$ & $5-8(6)$ & $3-7(6)$ & $3-10(7)$ & - & $3-9(7)$ & - & - \\
\hline 14 & $2,3(2)$ & $1,2(2)$ & n.c. & - & - & - & 1 & 1 & 1 & 1 & $1,2(1)$ & $1,2(1)$ & - \\
\hline 15 & $4-7(6)$ & - & - & - & - & - & - & - & - & - & - & - & - \\
\hline
\end{tabular}

$a$ : based on counts made on 11 to 20 setae; n.c.: not counted; P: prothorax; M: mesothorax; T: metathorax 
$0.44 \mathrm{~mm}$ (mean $=0.43 \mathrm{~mm}$ ), siphon/saddle index 2.33-2.65 (mean $=2.46$ ). Seta $2-X$ with 1 long and 4-6 short branches, 4-X with 6 pairs of setae, 3 anterior pairs with 7-10 branches, 3 posterior pairs with 4-10 branches. Anal papillae short and slender, gradually tapering to blunt tip, dorsal pair about $0.7(n=5)$ length of saddle, ventral pair about 0.9 $(n=3)$ length of saddle.

Diagnosis - The immature stages of $C x$. delpontei can be easily recognized by the following characters. Pupa: trumpet moderately tanned, flared, index 5.80-8.0; pinna large, about 0.45 of trumpet length, V-shaped; cephalothoracic integument lightly and evenly tanned; seta 1 -II weakly developed, with 5-20 branches; abdominal segments and paddle lightly tanned; caudolateral angle of segment VIII blunt; seta 1,2-P absent. Larva: seta $2-C$ present, well developed, inserted medially to $1-\mathrm{C}$; $3-\mathrm{C}$ present, minute; 5-C moderately long, not reaching anterior margin of head, with 6,7 strong, aciculate branches; median labral plate prominent, anterior margin between seta 1-C straight; 7-I single; 1-II well developed, multibranched; comb with 32-52 short scales interspersed with 4,5 long, strong, spinelike scales, short scales disposed in 2,3 irregular rows; siphonal index 5.55-7.23; seta 1-S in 6,7 posterior pairs and 4 anterior pairs; saddle and anal lobe finely spiculated, and anal papillae shorter than length of saddle.

Bionomics - Immature stages of $C x$. delpontei were collected in river, river edges and stream margin in modified environment and urban areas. The breeding sites were always permanent, in full sun. The water was fresh, clear with slow current and abundant floating (Pistia), submerged and emergent vegetation, and scarce green algae (Forattini et al. 1991).

Material examined - Fourteen larval exuviae, 20 pupal exuviae, with associated adults male and female, 10 fourth-instar larvae, bearing the following collection data: BRAZIL, State of São Paulo, Iguape County, Ribeira do Iguape River, Valo Grande Dam, 24.X.1989, coll. Gomes, 5 Le, 5 Pe, 2 4th-instar larvae; Palmeiras Farm, 5.IX.1989, 4 Le, 4Pe, 2 4th-instar larvae; 24.X.1989, 3 Le, 3Pe; 7.XI.1989, 2 Le, 8 Pe; 20.II.1990, 4 4th-instar larvae; State of Paraná, Cerro Azul County, 16.V.1991, coll. Natal, 2 4th-instar larvae.

\section{Culex (Melanoconion) pereyrai Duret, 1967}

Culex (Melanoconion) pereyrai Duret, 1967 : 81 ( $\left.{ }^{*} *\right)$. Holotype o* $^{*}$ : Cecilio Baez, Caaguazu, Paraguay (NMNH)

Pupa (Fig. 5) - Position and development of setae as figured; range and modal number of branches in Table V. Cephalothorax: lightly tanned, leg cases lightly tanned, sometimes speckled, wing cases with dark, discontinuously pigmented, longitudinal lines. Trumpet: moderately tanned, cylindrical, slightly wider beyond tracheoid area. Trumpet index 7.75-10.02 (mean =8.41); tracheoid area slightly darker, extending almost 0.40 from base; pinna large, narrow, V-shaped, about 0.37 of trumpet length; meatus with short slit. Abdomen: lightly tanned, tergum IX slightly darker than anterior segments; length 2.22-2.70 mm (mean $=2.43 \mathrm{~mm})(n=9)$. Seta 1-II with 5-10 weak

TABLE V

Pupal setal branching for Culex pereyrai: range, mode ( $)^{a}$

\begin{tabular}{cccccccccccc}
\hline \multirow{2}{*}{ Seta } & Cephalothorax & \multicolumn{7}{c}{ Abdominal segments } & & & Paddle \\
\cline { 3 - 11 } no. & & I & II & III & IV & V & VI & VII & VIII & IX & - \\
\hline 0 & - & - & - & 1 & 1 & 1 & 1 & 1 & 1 & - & - \\
1 & $2,3(3)$ & $6-11(9)$ & $5-10(7)$ & $3-8(6)$ & $3-6(4)$ & $2-4(3)$ & $2,3(2)$ & $1-3(2)$ & - & 1 & - \\
2 & $2-4(2)$ & 1 & 1 & 1 & 1 & 1 & 1 & 1 & - & - & - \\
3 & $2,3(2)$ & 1 & 1 & 1 & $3-5(4)$ & $1,2(2)$ & $1,2(2)$ & $1-3(2)$ & - & - & - \\
4 & $1-3(1)$ & $4-7(6)$ & $2-5(3)$ & $3-6(4)$ & $2,3(2)$ & $3-6(4)$ & $2-4(2)$ & $1-3(2)$ & $2,3(2)$ & - & - \\
5 & $2-4(3)$ & $2,3(2)$ & $2,3(3)$ & $3-6(4)$ & $3-5(4)$ & $2,3(2)$ & 2 & $1,2(1)$ & - & - & - \\
6 & $1-3(2)$ & $1,2(1)$ & 1 & $1,2(2)$ & 2 & 2 & 2 & $1-3(2)$ & - & - & - \\
7 & $1,2(2)$ & $1,2(1)$ & $1,2(2)$ & $3-5(4)$ & $2,3(3)$ & $3-5(5)$ & $1,2(1)$ & 1 & - & - & - \\
8 & $2,3(3)$ & - & - & $3,4(3)$ & $2-4(2)$ & $2-4(3)$ & $2,3(3)$ & $2-4(3)$ & - & - & - \\
9 & 2 & 1 & 1 & 1 & 1 & 1 & 1 & 1 & 1 & - & - \\
10 & $6-10(7)$ & alveolus & - & 1 & 1 & 1 & 1 & $1,2(1)$ & - & - & - \\
11 & $1,2(1)$ & 1 & - & 1 & 1 & 1 & 1 & $2,3(2)$ & - & - & - \\
12 & $1-3(2)$ & - & - & - & - & - & - & - & - & - & - \\
13 & - & - & - & - & - & - & - & - & - & - & - \\
14 & - & - & - & 1 & 1 & 1 & 1 & 1 & 1 & - \\
\hline
\end{tabular}

$a$ : based on counts made on 11 to 20 setae. 


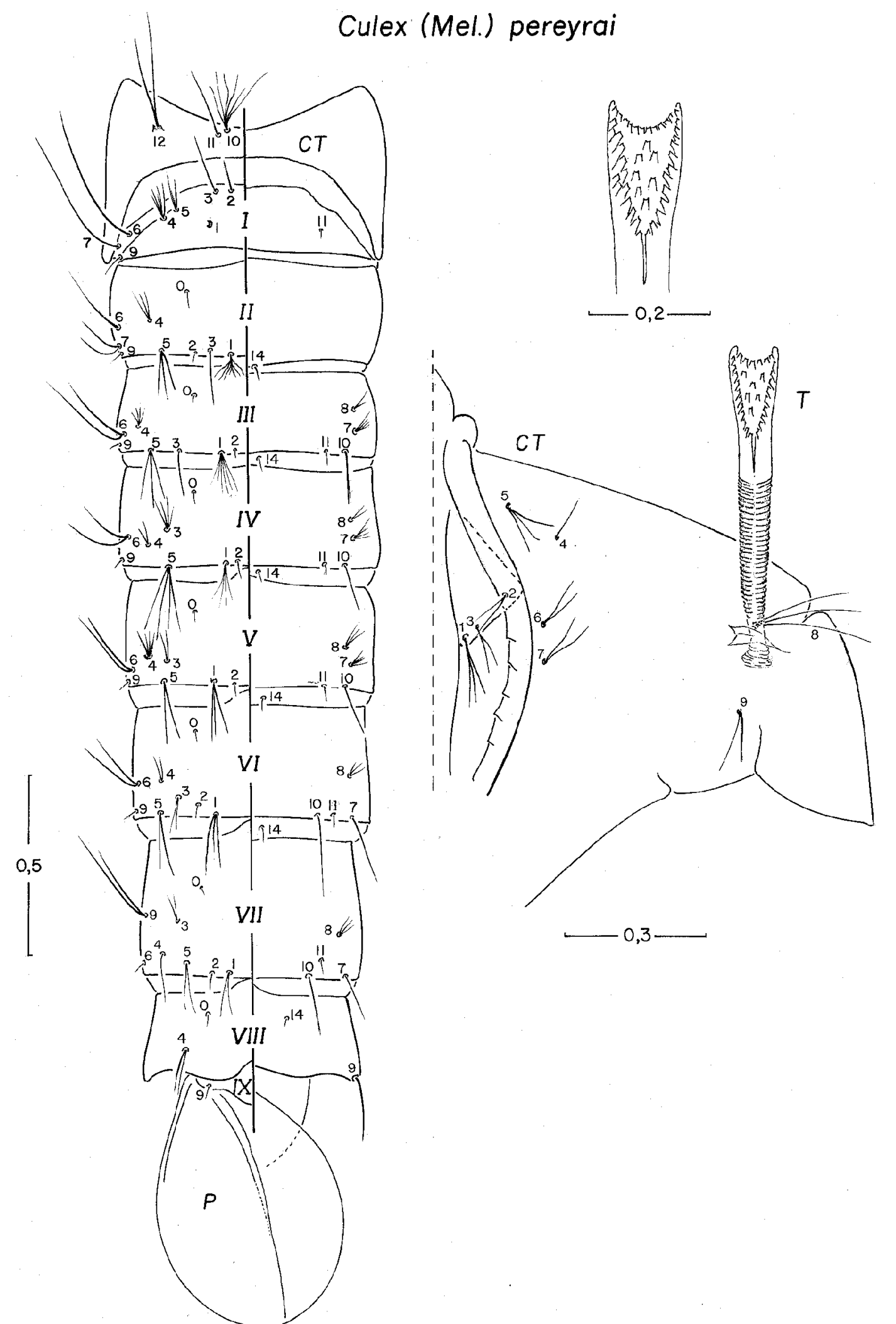

Fig. 5: Culex pereyrai. Pupa. CT: cephalothorax; P: paddle; T: trumpet; I-IX: abdominal segments, left side dorsal, right side ventral; scale in $\mathrm{mm}$ 
branches, 1-III-V with multiple, simple branches; 5-III with simple branches similar in development to 1-III, 5-IV-VI more developed than 1-IV-VI with minutely spiculated branches; 9-VIII inserted at caudolateral angle, always single. Caudolateral angle blunt. Genital lobe: lightly tanned in female, darker in male; length $0.13-0.16 \mathrm{~mm}$ (mean $=0.15$ $\mathrm{mm})(n=6)$, in female; $0.30-0.34 \mathrm{~mm}$ (mean $=0.31$ $\mathrm{mm})(n=4)$, in male. Paddle: lightly tanned, darker on inner side and apex, midrib strong except at apex; buttress developed at base only, margins smooth, length $0.67-0.76 \mathrm{~mm}$ (mean $=0.71 \mathrm{~mm})$; width $0.40-0.47 \mathrm{~mm}$ ( mean $=0.43 \mathrm{~mm})$, index 1.55 1.79 (mean $=1.63$ ); setae 1,2-P absent.

Larva (Fig. 6) - Position and development of setae as figured; range and modal number of branches in Table VI. Head: wider than long, length 0.66-0.87 mm (mean = 0.77 mm); width 0.98-1.01 $\mathrm{mm}($ mean $=0.99 \mathrm{~mm})(n=2)$; lightly tanned, darker on anterior part of dorsal apotome, collar and median labral plate. Median labral plate prominent, anterior margin between seta 1-C slightly concave. Dorsomentum nearly triangular with 1 large median tooth and 5 smaller, unequally developed teeth on each side. Antenal length 0.61$0.72 \mathrm{~mm}($ mean $=0.66 \mathrm{~mm})(n=9)$; antenna lightly tanned, darker on base and on apical 0.3; seta 1-A inserted about 0.62 from base, with 21-28 strong, aciculate branches; 2,3-A apical in position. Antenal puncture distinct. Seta 2-C present, well developed, inserted medially to seta $1-\mathrm{C} ; 3-\mathrm{C}$ present, minute; 4-C moderately long, extending slightly beyond the level of insertion of 7-C; 5-C well developed with 5,6 strong, densely aciculated branches; 6-C long with long aciculae. Thorax: integument hyaline with tiny spicules, these more evident laterally and on ventral surface; thoracic segments without patches of black pigment granules under integument. Seta 1,2-P with long aciculae; 3-P with 9-13 aciculate branches; 4-P densely aciculated; 1-M well developed with finely, aciculate branches; $1-\mathrm{T}$ less developed than 1-M with sparsely aciculated branches; 13-T well developed with finely aciculated branches. Abdomen: integument hyaline with minute spicules on central areas of segments, smooth laterally, spicules more developed on segment VIII; segments without band of black pigment granules under integument. Seta 1-I weakly developed, 1-II-V well developed with sparsely aciculated branches; 6-I, II long with strong, aciculate, unequal branches, 6III-VI nearly similar in development with finely aciculated branches. Comb with 15-23 short scales interspersed with 3-5 long, sharply pointed scales, short scales with distinct apical fringe, lateral fringe less developed, long scales without fringe on sides and apex, short scales disposed in 2 irregular rows.
Siphon: index 5.44-5.89 (mean = 5.68), moderately tanned, darker on apex and base, acus attached, long and slender on anterior side of attachment. Pecten of 6-10 spines on basal 0.3 of siphon; ventral edges of spines fringed with minute, closely set denticles. Seta 1-S usually in 10 pairs, 8 posterior pairs and 2 anterior pairs; posterior pairs with length 1.60 as long as width of siphon at point of insertion, the most anterior pair nearly as long as width of siphon at point of insertion, the most posterior pair nearly as long as width of siphon at point of insertion, the most posterior pair minute, inserted dorsally on posterior end of siphon. Seta 2-S arising in a membrane near base of anterolateral spiracular lobe, curved anteriorly with a small, curved, secondary branch near middle of anterior side. Segment X: saddle complete without accus, finely spiculated on dorsal side, anal lobe sparsely spiculated; length 0.36-0.42 $\mathrm{mm}$ (mean $=0.39 \mathrm{~mm}$ ), siphon/saddle index 2.52-2.68 (mean $=2.59)$. Seta $2-X$ with 1 long and 3-5 short branches, $4-X$ with 6 pairs of setae, 3 anterior pairs with 7-9 branches, 3 posterior pairs with 4-9 branches. Anal papillae short and slender, gradually tapering to blunt tip, dorsal pair about $0.70(n=4)$ length of saddle; ventral pair about $0.90(n=5)$ length of saddle.

Diagnosis - CX. pereyrai can be easily recognized by the following characters. Pupa: trumpet moderately tanned, index 7.75-10.02, pinna large, narrow, about 0.37 of trumpet length, $\mathrm{V}$-shaped; wing case lightly tanned with dark, discontinuously pigmented longitudinal lines, leg cases sometimes speckled; seta 1-II weakly developed with 5-10 branches; paddle lightly tanned, darker on apex and inner side; setae 1,2-P absent. Larva: seta 2-C present, well developed, arising mesad to 1-C; 3$\mathrm{C}$ present, minute; 5-C moderately long, not reaching anterior margin of head with 5,6 strong, aciculate branches; median labral plate prominent, anterior margin between seta 1-C concave; 7-I single; 1-II well developed, multibranched; comb with 15-23 short scales interspersed with 3-5 long, strong, spinelike scales, short scales disposed in 2 irregular rows; siphonal index 5.83-5.89; seta 1-S in 8 posterior pairs and 2 anterior pairs; saddle and anal lobe finely spiculated, and anal papillae shorter than length of saddle.

Bionomics - Immature stages of $C x$. pereyrai were collected in the same habitat of $C x$. delpontei and $C x$. ocossa, in close association with these species (Forattini et al. 1991).

Material examined - Seventeen larval exuviae, 22 pupal exuviae, with associated adult male and female and 2 fourth-instar larvae, bearing the following collection data: BRAZIL, State of São Paulo, Iguape County, Ribeira de Iguape River, Valo Grande Dam, 24.X.1989, coll. Gomes, 1 Le, 


\section{Culex (Mel.) pereyrai}
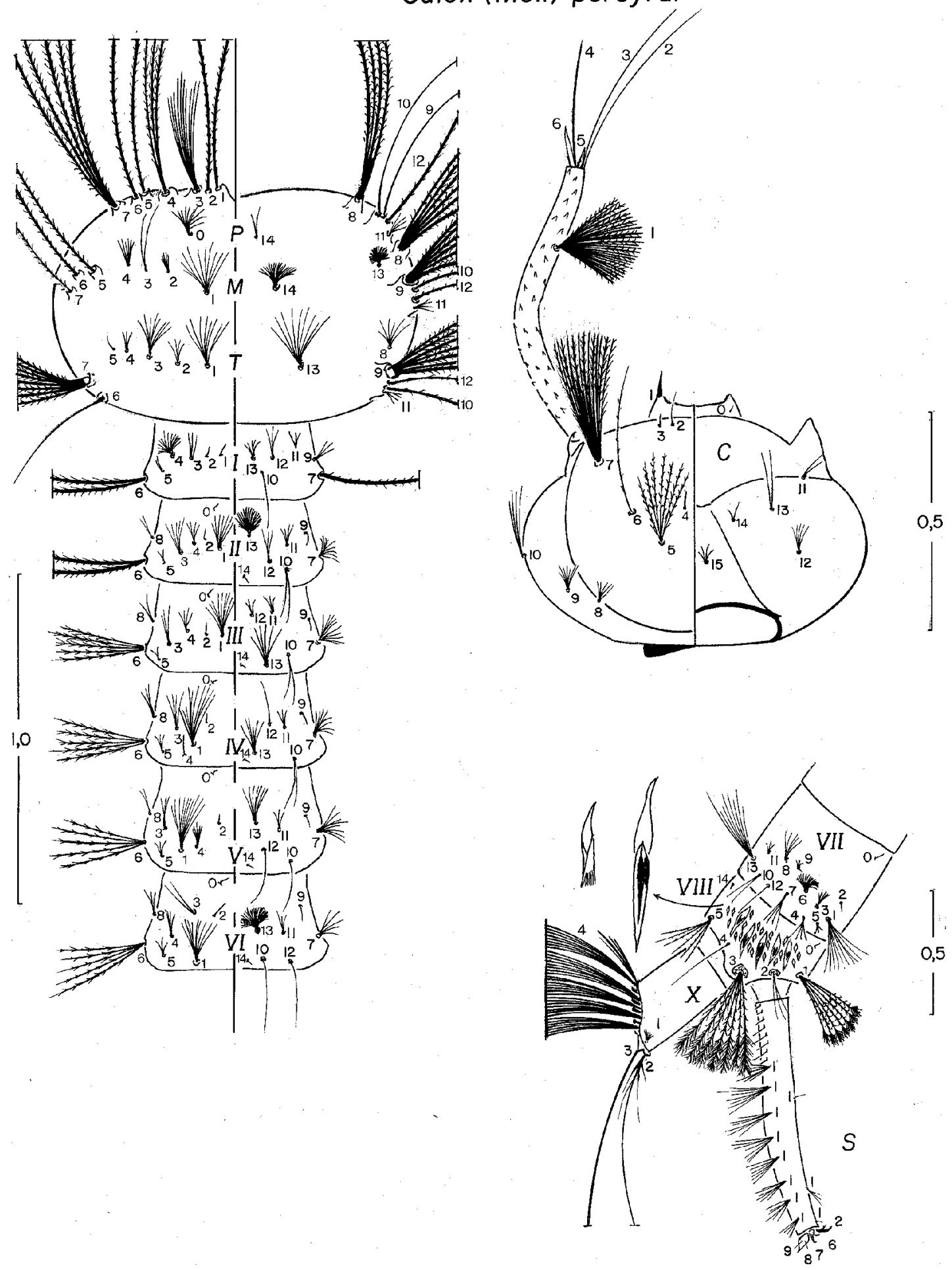

Fig. 6: Culex pereyrai. Larva. C: head; P: prothorax; M: mesothorax; S: siphon; T: metathorax; I-VIII: abdominal segments; X: anal lobe; scale in $\mathrm{mm}$ 
TABLE VI

Larval setal branching for Culex pereyrai: range, mode ( $)^{a}$

\begin{tabular}{|c|c|c|c|c|c|c|c|c|c|c|c|c|c|}
\hline \multirow{2}{*}{$\begin{array}{l}\text { Seta } \\
\text { no. }\end{array}$} & \multirow[t]{2}{*}{ Head } & \multicolumn{3}{|c|}{ Thorax } & \multicolumn{9}{|c|}{ Abdominal segments } \\
\hline & & $\mathrm{P}$ & M & $\mathrm{T}$ & I & II & III & IV & V & VI & VII & VIII & $\mathrm{X}$ \\
\hline 0 & alveolus & $8-13(10)$ & - & - & - & 1 & 1 & 1 & 1 & 1 & 1 & 1 & - \\
\hline 1 & 1 & 1 & $10-13(10)$ & $5-9(8)$ & $1,2(1)$ & $5-8(7)$ & $6-11(9)$ & $3-11(10)$ & $5-11(10)$ & $6-9(9)$ & $8-14(10)$ & $5-8(7)$ & $5-9(6)$ \\
\hline 2 & 1 & 1 & $4-6(5)$ & $2-5(4)$ & 1 & 1 & 1 & 1 & $1,2(1)$ & 1 & 1 & $2-4(3)$ & $4-6(5)$ \\
\hline 3 & 1 & $9-13(10)$ & $1-3(2)$ & $6-9(8)$ & $3-6(4)$ & $4-6(4)$ & $1-5(3)$ & $2-5(4)$ & 3 & $2,3(2)$ & $3-6(5)$ & $6-10(8)$ & 1 \\
\hline 4 & 1 & 3 & $4-9(6)$ & $2-4(3)$ & $10-17(14)$ & $5-9(5)$ & $2-5(4)$ & $1,2(1)$ & $6-9(8)$ & $3-7(5)$ & $3-5(4)$ & 1 & $5-9(8)$ \\
\hline 5 & $5,6(6)$ & 1 & 1 & 1 & $2,3(2)$ & $1,2(2)$ & $2,3(2)$ & $2-4(3)$ & $2-4(3)$ & $2-4(3)$ & $3-5(3)$ & 4-6(6) & - \\
\hline 6 & 1 & 1 & 1 & 1 & 2 & $1,2(2)$ & $4-6(5)$ & $4-7(5)$ & $5-7(6)$ & $4-7(5)$ & $12-17(16)$ & $1 \mathrm{a}-\mathrm{S}$ & $4-8(6)$ \\
\hline 7 & $11-14(13)$ & $4-6(5)$ & 1 & $6-10(8)$ & 1 & $7-10(9)$ & $9-12(10)$ & $8-12(8)$ & $3-11(8)$ & $5-8(5)$ & $4-8(4)$ & $1 b-S$ & $3-8(6)$ \\
\hline 8 & $3-7(5)$ & $3-5(4)$ & $5-7(6)$ & $5-8(6)$ & - & 2 & $2-4(2)$ & $2,3(3)$ & $2,3(2)$ & $2-4(3)$ & $4-7(5)$ & $1 \mathrm{c}-\mathrm{S}$, & $5-8(7)$ \\
\hline 9 & $4-10(7)$ & 1 & $4-6(6)$ & $6-9(7)$ & $3-5(3)$ & $1,2(1)$ & 1 & $1,2(1)$ & 1 & 1 & $2-5(3)$ & $1 \mathrm{~d}-\mathrm{S}$, & $6-8(7)$ \\
\hline 10 & $3-5(4)$ & 1 & 1 & 1 & 1 & 1 & $2-4(2)$ & 2 & 1 & 1 & $2-4(3)$ & 1e-S, & $3-9(7)$ \\
\hline 11 & $2,3(2)$ & $3-6(4)$ & $2-4(4)$ & $2-4(4)$ & $2-4(3)$ & $3-5(4)$ & $2,3(3)$ & $2-4(3)$ & $2-5(3)$ & $3,4(3)$ & $2-5(3)$ & $1 \mathrm{f}-\mathrm{S}$ & $5-9(7)$ \\
\hline 12 & $4-6(5)$ & 1 & 1 & 1 & $2-4(3)$ & $3,4(3)$ & $2,3(3)$ & $1-3(1)$ & 1 & 1 & 1 & $1 \mathrm{~g}-\mathrm{S}$, & $3-8(6)$ \\
\hline & & & & & & & & & & & & $1 \mathrm{~h}-\mathrm{S}$, & $2-9(6)$ \\
\hline & & & & & & & & & & & & $1 \mathrm{i}-\mathrm{S}$ & $1-4(4)$ \\
\hline & & & & & & & & & & & & $\mathrm{lj}-\mathrm{S}$, & 1 \\
\hline 13 & $1-3(2)$ & - & n.c. & $7-12(9)$ & $3-5(5)$ & $17-25(20)$ & $4-8(6)$ & $3-8(6)$ & $4-9(7)$ & $32-44(39)$ & $4-9(8)$ & $2-S$ & 2 \\
\hline 14 & 2 & 2 & n.c & - & - & - & 1 & 1 & 1 & 1 & 1 & 1 & - \\
\hline 15 & $3-6(4)$ & - & - & - & - & - & - & - & - & - & - & - & - \\
\hline
\end{tabular}

$a$ : based on counts made on 10 to 20 setae; n.c.: not counted; P: prothorax; M: mesothorax; T: metathorax 
1Pe; Palmeiras Farm, 22.VIII.1989, 2 Le, 2Pe; 5.IX.1989, 8 Le, 8 Pe; 19.IX.1989, 1 Le, 1Pe; 7.XI.1990, 1 Le, 6 Pe, 1 4th-instar larva; 5.XII.1989, 4Le, 4Pe; 20.II.1990, 1 4th-instar larva; Pariquera-Açu County, Experimental Station, Jacupiranga River, 30.XI.1989, coll. Gomes, 1 Le, 1 Pe.

\section{DISCUSSION}

By means of a series of morphological comparisons made on larval stage of the known species of the Spissipes Section of Cx. (Melanoconion), we came to the conclusion that the species of this section are similar in possessing seta 5$\mathrm{C}$ well developed with strong, heavily aciculated branches, seta $2-X$ with 1,2 long central branches, bearing 1-4 short branches on both sides of basal end, saddle of segment X smooth or with tiny spicules on lateral areas at posterior end, and a minute pair of seta 1-S at apex of dorsal side of siphon. Based on morphological features of adult male and female, Sallum \& Forattini (1996) confirmed $C x$. ocossa to be a member of the Ocossa group, and $C x$. delponte $i$ and $C x$. pereyrai were shown to be members of the Crybda group. The Crybda group was divided into three subgroups, Pedroi, Paracrybda and Pereyrai. The larva of $C x$. delpontei (Paracrybda subgroup) and that of $C x$. pereyrai (Pereyrai subgroup) can be easily distinguished from those of the species of the Pedroi subgroup by having seta 7-I single, and comb scales with short, apically fringed scales which are interspersed with strong, large, spinelike scales. In contrast, all the species included in the Pedroi subgroup (immatures of $C x$. crybda are unknown) have seta 7-I double, and comb scales similar in shape with apical fringe of fine spicules. The larval stage of these three species share the presence of a well developed seta $2-\mathrm{C}$ which is inserted medially to seta 1-C, and a minute seta 3-C; the pupa is similar in having seta 3-I, II and 9-VII, VIII usually single, and 1-II weakly developed, and by the absence of seta 2-P. However, $C x$. ocossa, Cx. delpontei and $C x$. pereyrai can be easily distinguished from each other by the following characters. Pupa: In $C x$. ocossa the trumpet is flared, trumpet index 6.09.0 , pinna large, $\mathrm{V}$-shaped about 0.42 of trumpet length, wing and leg cases usually speckled, seta 5-IV-VI dark with strong, densely aciculated branches, caudolateral angle of segment VIII produced into sharp point, paddle dark on apex and nearly all inner side, and seta 1-P present; in $C x$. delpontei the trumpet is similar in shape to that of Cx. ocossa, trumpet index 5.80-8.0, wing and leg cases lightly tanned without pattern of dark spots, seta 5-IV-VI less developed and less aciculated than those of $C x$. ocossa, caudolateral angle of segment
VIII blunt, paddle lightly tanned and setae 1,2-P absent; in Cx. pereyrai trumpet is cylindrical, pinna about 0.37 of trumpet length, narrow, nearly of the same diameter as meatus, trumpet index 7.7510.02 , wing case with pattern of longitudinal dark lines, leg cases speckled, seta 5-IV-VI and caudolateral angle of segment VIII similar to those of $C x$. delpontei, paddle dark on apex and inner side as in Cx. ocossa, and setae 1,2-P absent. Larva: in $C x$. ocossa, anterior margin of median labral plate between seta 1-C concave, seta 6-C moderately short with tiny aciculae, comb scales with 1325 short scales, disposed in an irregular row, interspersed with 4-6 long, strong, sharply pointed, spinelike scales, siphonal index 4.47-5.31, seta 1$\mathrm{S}$ in 6 posterior pairs and 2 anterior pairs, all posterior pairs inserted subventrally; in $C x$. delpontei the anterior margin of median labral plate between seta 1-C straight, seta 6-C similar to that of $C x$. ocossa but with longer aciculae, comb scales with 32-52 short scales, disposed in 2,3 irregular rows, interspersed with 4,5 long, strong, sharply pointed, spinelike scales, these scales stronger than those of $C x$. ocossa and $C x$. pereyrai, siphonal index 5.55-7.23, seta 1-S in 6,7 posterior pairs and 4 anterior pairs, the most proximal posterior pair arising laterally, the other posterior pairs, subventrally; in $C x$. pereyrai anterior margin of median labral plate between seta 1-C concave as in $C x$. ocossa, seta 6-C longer than that of $C x$. ocossa and $C x$. delpontei with longer aciculae than in $C x$. delpontei, comb scales with 15-23 short scales, disposed in 2 irregular rows, interspersed with 3-5 long, strong, sharply pointed, spinelike scales, these scales stronger than those of $C x$. ocossa but less developed than those of $C x$. delpontei, siphonal index 5.445.89 and seta $1-\mathrm{S}$ in 7,8 posterior pairs and 2 anterior pairs, all posterior pairs inserted subventrally.

\section{ACKNOWLEDGMENTS}

To RP Domingues for typing the manuscript and Mr DC Flores for labelling figures 1-6.

\section{REFERENCES}

Belkin JN, Heinemann SJ, Page WA 1970. Mosquito studies (Diptera, Culicidae). XXI. The Culicidae of Jamaica. Contrib Am Entomol Inst (Ann Arbor) 6: $1-458$.

Forattini OP, Gomes AC, Kakitani I, Marucci D 1991. Observações sobre domiciliação de mosquitos Culex (Melanoconion) em ambiente com acentuadas modificações antrópicas. Rev Saúde Públ 25: 257266.

Galindo P 1972. Endemic vectors of Venezuelan encephalitis. PAHO Sc Publ 243: 249-253.

Galindo P, Adames AJ 1973. Ecological profile of Culex (Melanoconion) aikenii (Diptera, Culicidae), vector of endemic Venezuelan encephalitis in Panama. Environ Entomol 2: 81-86. 
Galindo P, Grayson MA 1971. Culex (Melanoconion) aikenii: natural vector in Panama of endemic Venezuelan encephalitis. Science 172: 594-595.

Heinemann SJ, Belkin JN 1978a. Collection records of the project "Mosquitoes of Middle America" 10. Panama, including Canal Zone (PA, GG). Mosq Syst 10: 119-196.

Heinemann SJ, Belkin JN 1978b. Collection records of the project "Mosquitoes of Middle America" 11. Venezuela (VZ); Guianas: French Guyana (FG, FGC), Guyana (GUY), Surinam (SUR). Mosq Syst 10: 365-459.

Heinemann SJ, Belkin JN 1979. Collection records of the project "Mosquitoes of Middle America" 13. South America: Brazil (BRA, BRAP, BRB), Ecuador (ECU), Peru (PER), Chile (CH). Mosq Syst 11: 61-118.

Mitchell CJ, Monath TP, Sabattini MS, Cropp CB,
Daffner JF, Calisher CH, Jakob WL, Christensen HA 1985. Arbovirus investigations in Argentina, 19771980, II. Arthropod collections and virus isolations from Argentine mosquitoes. Am J Trop Med Hyg 34: 945-955.

Mitchell CJ, Monath TP, Sabattini MS, Daffner JF, Cropp CB, Calisher CH, Darsie Jr RF, Jakob WL 1987. Arbovirus isolations from mosquitoes collected during and after the 1982-1983 epizootic of western equine encephalitis in Argentina. Am J Trop Med Hyg 36: 107-113.

Sallum MAM, Forattini OP 1996. Revision of the Spissipes Section of Culex (Melanoconion) (Diptera: Culicidae). Mosq Syst 12: 517-600.

Sirivanakarn S, Jakob WL 1981 . Notes on distribution of Culex (Melanoconion) mosquitoes in northeastern Argentina (Diptera: Culicidae). Mosq Syst 13: 195-199. 
Immature Stages of Cx. (Melanoconion) Species - Maria Anice Mureb Sallum et al. 